\title{
MUTU KIMIA DAN ORGANOLEPTIK KECAP IKAN LAYANG (Decapterus spp.) DENGAN PENAMBAHAN ENZIM BROMELIN
}

\author{
Eka Aji Pramita ${ }^{1)^{*}}$, Finarti $^{1)}$, Renol $^{1)}$, dan Radhiyatul Ula ${ }^{1)}$ \\ ${ }^{1}$ Sekolah Tinggi Perikanan dan Kelautan Palu (STPL Palu) \\ Jl. Soekarno Hatta KM 6 Palu, Sulawesi Tengah, Indonesia \\ Email: ekapramita@stplpalu.ac.id
}

\begin{abstract}
Fish sauce is a fishery product made from fish meat raw materials in two ways: traditional fermentation and enzymatic fermentation. Fish sauce is easy and cheap to make and is popular with the public. Fermentation breaks down complex compounds in the fish body into simpler compounds by enzymes originating from the fish's body itself or microorganisms and taking place under controlled environmental conditions. One of the factors that influence fermentation activities is the type of enzyme used. Bromelain enzyme is a type of sulfhydryl protease enzyme that can hydrolyze protein - adding enzymes before fermentation can shorten the time in making the fish sauce (because there is no need for adaptation time for microorganisms to produce enzymes that can hydrolyze protein). This study aimed to determine the effect of bromelain enzyme concentrations on the chemical and organoleptic quality of flying fish sauce (Decapterus spp). The research results showed that the enzyme bromelain concentration has a very significant effect on chemical quality (viscosity) and organoleptic quality (odor and color). The K1 treatment $(200 \mathrm{ml})$ had the highest value on the assay of viscosity (3,698\%), aroma $(2,425)$, and color $(2,738)$.
\end{abstract}

Keywords: Bromelin Enzyme, Fish Sauce, Flying Fish,

\section{PENDAHULUAN}

Ikan merupakan sumber pangan hewani yang sudah tidak asing lagi di masyarakat. Jenis ikan merupakan bahan pangan sumber protein hewani yang relatif murah dibandingkan dengan sumber protein hewani lainnya. Disamping menyediakan protein hewani yang relatif tinggi jumlahnya, ikan juga mengandung asam lemak tak jenuh, berbagai macam vitamin dan mineral yang sangat diperlukan oleh tubuh (Muchtadi et al., 2007).

Ikan layang (Decapterus spp) adalah salah satu jenis ikan yang cukup banyak ditangkap dan melimpah di Sulawesi Tengah. Pemanfaatan diversifikasi produk ke bentuk olahan belum optimal karena hanya terbatas pada konsumsi skala rumah tangga. Selain itu ikan ini cepat sekali mengalami penurunan mutu yang menyebabkan rasa gatal apabila dikonsumsi sehingga banyak masyarakat yang kurang menyukai jenis ikan ini. Oleh karena itu dilakukan pengawetan dan pengolahan secara fermentasi menjadi kecap ikan.

Fermentasi merupakan cara pengolahan bahan, dalam prosesnya menguraikan senyawa kompleks menjadi senyawa-senyawa yang lebih sederhana dengan bantuan enzim serta berlangsung dalam keadaan terkontrol atau diatur. Selama proses fermentasi, protein ikan akan terhidrolisis menjadi asam-asam amino dan peptida, kemudian asam-asam amino akan terurai lebih lanjut menjadi komponenkomponen lain yang berperan dalam pembentukan cita rasa produk. Beberapa contoh makanan hasil fermentasi yang terjadi pada ikan yaitu : kecap ikan, ikan peda, pasta ikan dan lain-lain (Adawyah, 2007).

Kecap ikan adalah salah satu produk perikanan yang dibuat dari bahan baku daging ikan dengan dua cara yaitu fermentasi cara tradisional dan enzimatis. Kecap ikan sangat digemari oleh masyarakat 
KAUDERNI : Journal of Fisheries, Marine and Aquatic Science

https://jurnal.stplpalu.ac.id/index.php/kauderni/index

Volume 2, Nomor 2, (2020)

ISSN 2541-0571

https://doi.org/10.47384/kauderni.v2i2.48

karena selain rasanya gurih juga pembuatannya mudah dan murah (Suprapti, 2008).

Enzim bromelin termasuk kelompok enzim protease sulfidril yang artinya memiliki residu sulfidril pada lokasi aktifnya. Sebagai enzim proteolitik, bromelin dapat menghidrolisa protein menjadi asam-asam amino sehingga dapat dimanfaatkan dalam proses pembuatan kecap. Enzim bromelin ini paling banyak ditemukan dalam buah nenas terutama pada bonggol ataupun pada buah yang masih muda. Enzim bromelin pada buah nenas juga dapat digunakan untuk mempersingkat waktu fermentasi pembuatan kecap ikan. Dalam hal ini tidak diperlukan lagi waktu adaptasi mikroorganisme untuk menghasilkan enzim yang dapat menghidrolisis protein (Hamidi, 2008).

Penelitian bertujuan untuk

mengetahui pengaruh penambahan enzim bromelin terhadap mutu kimia dan organoleptik kecap Ikan layang (Decapterus spp), sedangkan manfaatnya yaitu dapat memberikan informasi ilmiah bagi masyarakat luas tentang pengaruh pemberian enzim bromelin pada pembuatan kecap ikan dan sebagai acuan bagi penelitian lebih lanjut.

\section{METODE PENELITIAN}

Penelitian dilaksanakan pada bulan Juli 2020. Penelitian dilaksanakan di Laboratorium Teknologi Hasil Perikanan Sekolah Tinggi Perikanan dan Kelautan (STPL) Palu. Bahan baku yang digunakan adalah ikan layang (Decapterus spp) segar dengan ukuran $\pm 15 \mathrm{~cm}$ dan enzim bromelin yang diekstrak dari buah nenas muda, sedangkan bahan pembantu lainnya air sebagai pembersih dan akuades. Alat yang digunakan dalam penelitian adalah pisau, talenan, baskom, blender, toples kaca, kain saring, inkubator, timbangan analitik, piring Styrofoam, viskometer, $\mathrm{pH}$ meter, piknometer, pipet tetes, gelas ukur, statif dan klam, pompa karet, lembar skor sheet.

Penelitian ini menggunakan Rancangan Acak Lengkap (RAL) dengan 3 (tiga) perlakuan, Setiap perlakuan diulang sebanyak 4 kali, sehingga satuan percobaan sebanyak 3 x $4=12$. Perlakuan yang diterapkan dalam penelitian ini adalah konsentrasi enzim bromelin yang di ekstraksi dari buah nenas dapat dilihat pada Tabel 1.

Tabel 1. Perlakuan kosentrasi Enzim Bromelin

\begin{tabular}{cc}
\hline $\begin{array}{c}\text { Kode } \\
\text { Perlakuan }\end{array}$ & $\begin{array}{c}\text { Konsentrasi Enzim } \\
\text { Bromelin }\end{array}$ \\
\hline K1 & $200 \mathrm{ml}$ \\
K2 & $250 \mathrm{ml}$ \\
K3 & $300 \mathrm{ml}$ \\
\hline
\end{tabular}

Proses ekstraksi enzim bromelin dapat dilakukan melalui beberapa tahapan, yaitu buah nenas yang muda dibersihkan terlebih dahulu, kemudian diambil daging dan bongkol buahnya lalu dipotong dadu. Setelah itu, nenas digiling dengan menggunakan blender untuk mendapatkan ekstrak buah nenas (tanpa menggunakan air). Hasil ekstraksi diukur sesuai dengan perlakuan $(200 \mathrm{ml}, 250 \mathrm{ml}, 300 \mathrm{ml})$. Enzim bromelin hasil ekstraksiyang belum digunakan disimpan dalam wadah yang hampa udara (toples kaca) untuk menghindari kontaminasi langsung dengan lingkungan sekitar. Untuk lebih jelasnya diagram alir proses ekstraksienzim bromelin dapat dilihat pada Gambar 1.

Prosedur Pengolahan Fermentasi kecap ikan layang dilakukan dengan metode enzimatis, enzim yang digunakan dalam metode ini adalah enzim bromelin yang berasal dari ekstrak buah nenas. Berikut prosedur pengolahan fermentasi kecap ikan Layang (Decapterus spp), yaitu pertama bahan baku dicuci hingga bersih dan dilanjutkan dengan pemfiletan. Lalu, daging ikan dipotong dan digiling sampai halus menggunakan blender. Setelah halus, daging ikan seberat $50 \mathrm{~g}$ masing-masing dimasukan kedalam toples yang telah disterilkan sebelumnya. Enzim yang diekstrak dari buah nenas ditambahkan dengan takaran $200 \mathrm{ml}$, $250 \mathrm{ml}, 300 \mathrm{ml}$. Selanjutnya wadah ditutup dengan baik dan dibiarkan selama tiga (3) hari untuk memberikan kesempatan terjadinya fermentasi daging ikan. Akibat proses fermentasi, akan terbentuk cairan 
KAUDERNI : Journal of Fisheries, Marine and Aquatic Science

https://jurnal.stplpalu.ac.id/index.php/kauderni/index

Volume 2, Nomor 2, (2020)

ISSN 2541-0571

https://doi.org/10.47384/kauderni.v2i2.48

yang berasal dari tubuh ikan. Cairan yang terbentuk segera disaring agar bersih dari kotoran yang mungkin masih ada. Hasil penyaringan tersebut kemudian dimasukkan kedalam botol dan siap untuk di analisis. Untuk lebih jelasnya pembuatan kecap ikan layang dapat dilihat pada Gambar 2.

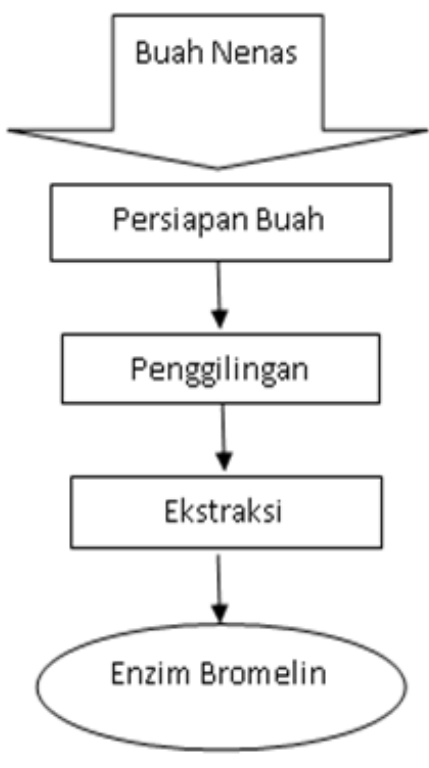

Gambar 1. Diagram Alir Proses Ekstraksi Enzim Bromelin

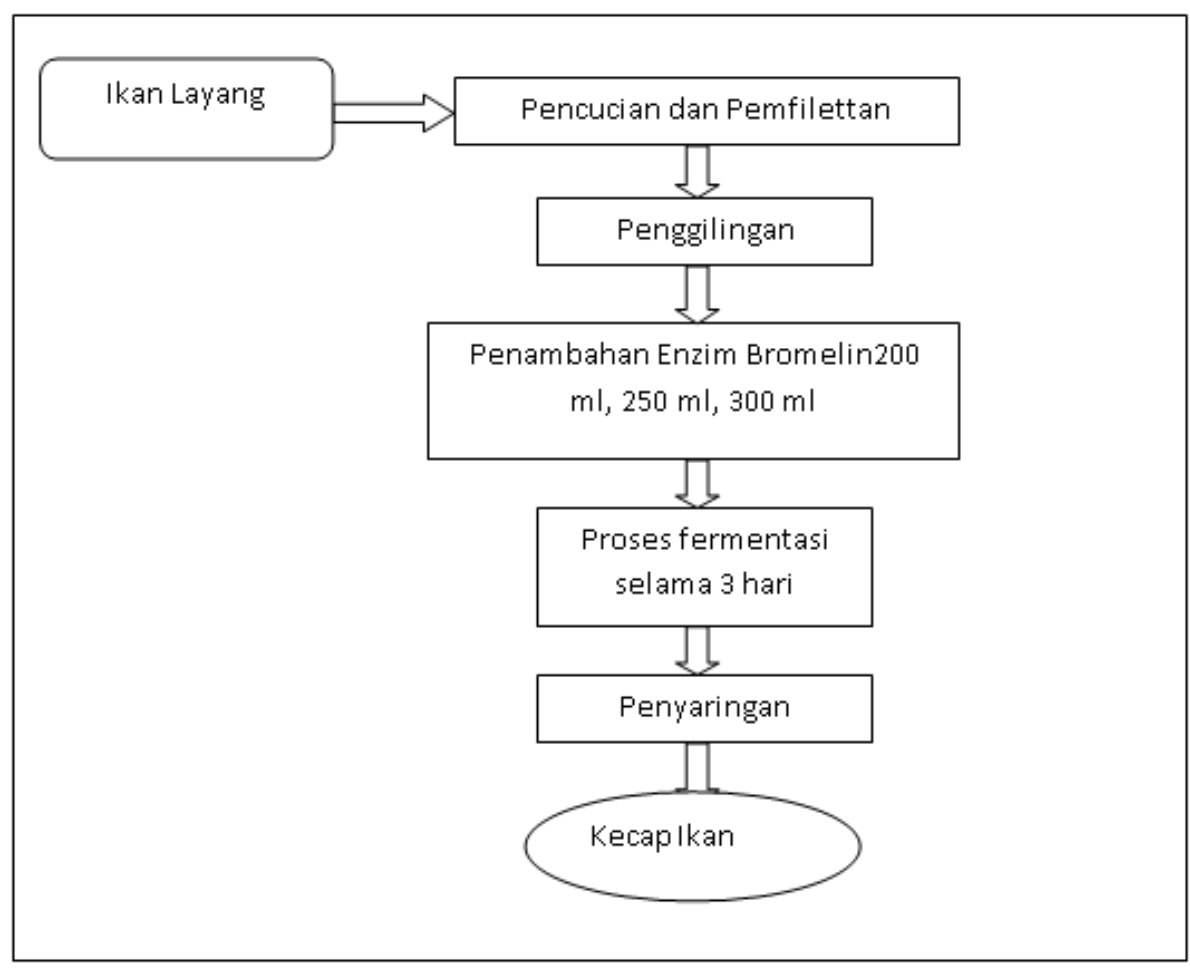

Gambar 2. Diagram Alir Pembuatan Kecap Ikan Layang 
KAUDERNI : Journal of Fisheries, Marine and Aquatic Science

https://jurnal.stplpalu.ac.id/index.php/kauderni/index

Volume 2, Nomor 2, (2020)

ISSN 2541-0571

https://doi.org/10.47384/kauderni.v2i2.48

\section{Peubah yang Diamati \\ Viskositas}

British Standard, (1975) menjelaskan bahwa larutan kecap dengan konsentrasi 5 $\mathrm{ml}$ disiapkan dengan melarutkan dalam akuades, larutan diaduk menggunakan magnetic strirer sampai homogen, kemudian dipanaskan sampai suhu $60^{\circ} \mathrm{C}$ selama 15 menit, kemudian diukur viskositasnya dengan menggunakan alat brookfield syncro-lectric viskometer. Hasil pengukuran dilakukan dengan faktor konversi, dimana nilai viskositas dinyatakan dalam satuan centi poise $(\mathrm{Cp})$.

\section{Uji Organoleptik}

Cara uji yang digunakan mengikuti petunjuk Soekarto (1994), yaitu sampel disajikan sekaligus kepada setiap panelis. Panelis yang digunakan adalah panelis tak terlatih, bahan disajikan secara acak dengan memberikan kode tertentu. Bau dan warnadiuji secara organoleptik dengan tujuan untuk mengetahui tingkat kesukaan (Consumer preference) terhadap kecap hasil fermentasi ikan layang dengan metode enzimatis.

Pengujian dilakukan oleh 20 panelis. Panelis diminta untuk memberikan penilaian

Tabel 2. Skor Sheet Penilaian Organoleptik

\begin{tabular}{cc}
\hline Skala Hedonik & Skala Numerik \\
\hline Suka & 5 \\
Agak Suka & 4 \\
Netral & 3 \\
Agak Tidak Suka & 2 \\
Tidak suka & 1 \\
\hline
\end{tabular}

Sumber : Soekarto (1994) berdasarkan tingkat kesukaannya dengan skor yang digunakan dapat dilihat pada Tabel 2.

\section{Analisis Data}

Data hasil pengamatan dianalisis secara statistik menurut persamaan (1) (Steel dan Torrie, 1991).

Dimana :

$$
\text { Yij }=\mu+\mathrm{Ti}+\varepsilon \mathrm{ij} \ldots(1)
$$

Yij : Respon terhadap perlakuan ke-i pada ulangan ke-j

$\mu \quad$ : Rata-rata umum pengamatan

Ti : Pengaruh perlakuan ke-i yang diuji

eij : Galat percobaan dari perlakuan ke-i pada pengamatan ke-j

i : Perlakuan $(1,2,3)$

j : Ulangan $(1,2, \ldots .4)$

Jika perlakuan yang diterapkan berpengaruh nyata,maka akan dilakukan uji lanjut dengan menggunakan Uji Beda Nyata Terkecil (BNT) (Hanafiah, 2001). Adapun model matematikanya persamaan (2).

$\mathrm{BNT} \alpha=\mathrm{t}_{\mathrm{a}(\mathrm{db} \text { galat })} \times \sqrt{\frac{2 \times \mathrm{KT} \text { Galat }}{\text { ulangan }}} \ldots$

Keterangan : $t_{a}$ dicari pada tabel $t$ untuk uji BNT

\section{HASIL DAN PEMBAHASAN}

Viskositas

Data hasil pengamatan viskositas kecap ikan layang dengan konsentrasi nenas (enzim) yang berbeda dapat dilihat pada Tabel 3.

Tabel 3. Nilai Rerata Viskositas Kecap Ikan Layang Dengan Konsentrasi Nenas Yang Berbeda.

\begin{tabular}{ccc}
\hline Perlakuan & $\begin{array}{c}\text { Rerata } \\
(\mathbf{\%})\end{array}$ & $\begin{array}{c}\text { BNT } \\
\mathbf{1 \%}(\mathbf{0 , 0 1})\end{array}$ \\
\hline Konsentrasi 200 ml & $3,698^{\mathrm{a}}$ & \\
Konsentrasi 250 ml & $3,115^{\mathrm{b}}$ & 0,205 \\
Konsentrasi 300 ml & $2,812^{\mathrm{c}}$ & \\
\hline
\end{tabular}

Keterangan : Angka yang diikuti oleh huruf yang berbeda menunjukkan perbedaan yang sangat nyata pada uji BNT 1\% $=0,05$

Dari Tabel 3. terlihat bahwa secara umum nilai viskositas kecap ikan dengan konsentrasi nenas yang berbeda menunjukkan hasil yang berbeda. 
KAUDERNI : Journal of Fisheries, Marine and Aquatic Science

https://jurnal.stplpalu.ac.id/index.php/kauderni/index

Volume 2, Nomor 2, (2020)

ISSN 2541-0571

https://doi.org/10.47384/kauderni.v2i2.48

Viskositas tertinggi terjadi pada perlakuan (K1) dengan konsentrasi nenas $200 \mathrm{ml}$ yaitu sebesar $3,698 \%$ dan nilai terendah viskositas terdapat pada perlakuan (K3) dengan konsentrasi $300 \mathrm{ml}$ yaitu sebesar $2,812 \%$, sedangkan untuk perlakuan (K2) dengan konsentrasi $250 \mathrm{ml}$ memiliki nilai rerata sebesar 3,115\%. Hal ini diduga karena pada perlakuan (K1) memiliki kelengketan yang lebih besar, dimana kadar terlarut lebih banyak dan pelarut lebih sedikit sehingga menimbulkan gaya gesek pada alat (buret) menjadi besar. Jumlah zat terlarut dalam fluida akan berpengaruh terhadap gesekkan internal antara zat partikel tersebut.

Berdasarkan analisis BNT menunjukkan bahwa nilai viskositas pada perlakuan K2 $(250 \mathrm{ml})$ berbeda sangat nyata terhadap perlakuan $\mathrm{K} 3(300 \mathrm{ml})$ dan perlakuan K1 (200 ml). Hal ini dikarenakan jumlah cairan kecap yang dihasilkan pada masing-masing perlakuan memiliki perbedaan volume sehingga mempengaruhi nilai viskositas, dimana viskositas cairan turun dengan bertambahnya volume dan koefisien cairan naik dengan berkurangnya volume. Semakin sedikit volume maka semakin kental kecap yang dihasilkan.

$$
\text { British Standard, }
$$

menyatakan lapisan-lapisan zat cair yang bergerak cepat satu sama lain akan saling bergesekan dan memberikan gaya gesek antar lapisan. Gaya gesek tersebut akan menahan aliran yang besarnya tergantung pada kekentalan zat. Ukuran gaya internal atau resistensi yang diberikan oleh suatu zat cair terhadap gaya gesek terapan ini disebut koefisien viskositas atau sering disebut angka kental.

Nilai viskositas yang dihasilkan pada setiap perlakuan, konsentrasi nenas $200 \mathrm{ml}$ pada perlakuan (K1) memiliki nilai yang tertinggi yaitu sebesar 3,698\%. Hal ini diduga, peningkatan nilai viskositas kecap ikan layang disebabkan perbandingan kadar terlarut (daging ikan) dan pelarut (enzim) lebih sedikit maka volume yang dihasilkan juga akan berkurang, sehingga dapat mempengaruhi kekentalan kecap ikan. Pada perlakuan $\mathrm{K} 2(250 \mathrm{ml})$ dan $\mathrm{K} 3(300 \mathrm{ml})$, viskositas mengalami penurunan dengan bertambahnya jumlah pelarut. Hal ini dapat menjelaskan bahwa jumlah zat terlarut akan berpengaruh terhadap gaya gesek antar lapisan. Kecap memiliki kelengketan yang lebih besar, sehingga gaya gesek yang ditimbulkan menjadi lebih besar. Perbedaan nilai rerata viskositas kecap ikan layang dengan konsentrasi nenas yang berbeda, lebih jelas dapat dilihat pada Gambar 3. Berdasarkan grafik diatas kisaran viskositas kecap ikan dari hasil fermentasi dari berbagai perlakuan adalah antara $2,812 \%$ $3,698 \%$.

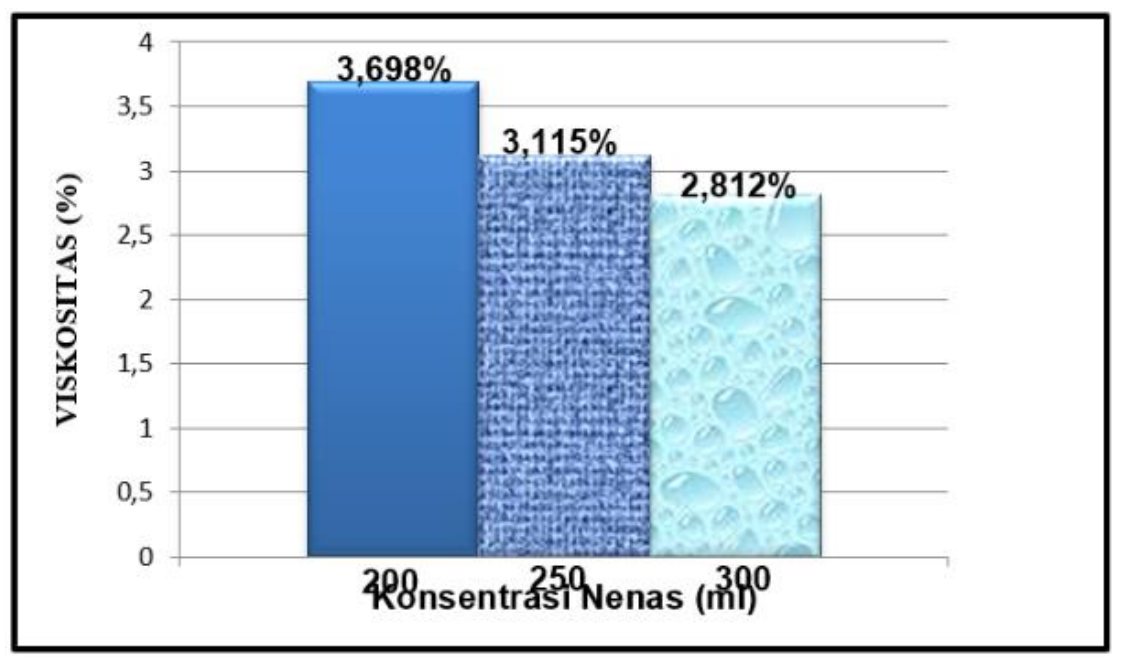

Gambar 3. Diagram Nilai Rerata Viskositas Kecap Ikan Layang Dengan Konsentrasi Nenas Yang Berbeda. 


\section{Mutu Organoneptik Kecap Ikan Layang Nilai Bau}

Winarno (1991), menyatakan bahwa dalam banyak hal kelezatan makanan ditentukan oleh bau/aroma produk tersebut. Bau dapat dikenali oleh indera penciuman bila berbentuk uap. Bau ini merupakan salah satu faktor penting bagi konsumen untuk memilih produk makanan yang disukai. Pembauan disebut juga pencicipan jarak jauh karena manusia dapat mengenal enaknya makanan yang belum terlihat hanya dengan mencium bau atau aroma makanan tersebut dari jarak jauh.

Soekarto (1994), aroma merupakan hasil dari komponen volatile seperti $\mathrm{H}_{2} \mathrm{~S}$, merkaptan, sulfida, disulfida, aldehida, keton, alkohol, aminvolatil ditambah dengan komponen-komponen volatile yang terbentuk akibat pemecahan lemak seperti aldehida, keton, alkohol, asam dan hidrokarbon. Hasil analisis sidik ragam Bau kecap ikan memberikan pengaruh tidak nyata $(P>0,05)$, hal ini dikarenakan enzim bromelin yang berperan mengurai protein dari tubuh ikan menjadi asam amino mengalami oksidasi sehingga terbentuk asam lemak bebas yang menyebabkan bau disetiap perlakuan sama.

Hasil penilaian panelis terhadap bau kecap ikan layang berkisar antara 2,225 2,425 yang berarti tingkat kesukaan panelis mulai dari agak suka sampai suka. Hal ini diduga karena penambahan enzim bromelin untuk semua perlakuan menghasilkan bau/aroma nenas yang sama menyebabkan penilaian panelis terhadap produk ini cenderung tetap. Untuk lebih jelasnya tentang penilaian panelis terhadap bau kecap ikan, dapat dilihat pada Gambar 4.

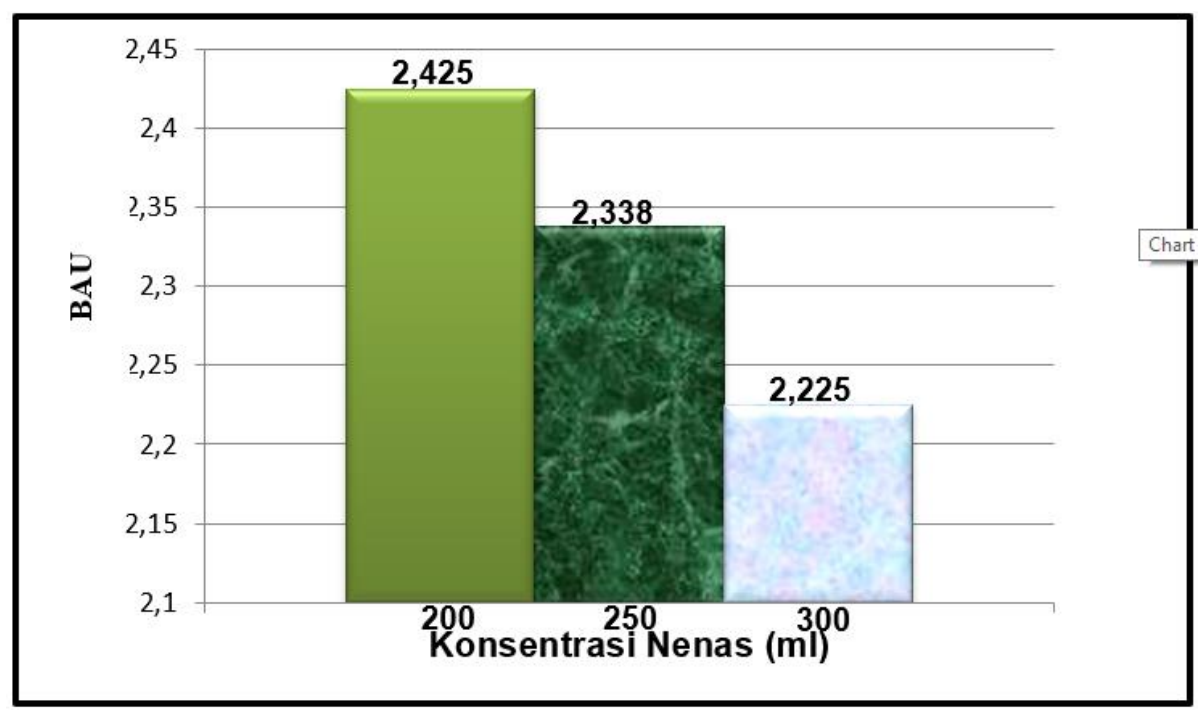

Gambar 4. Diagram Rerata Nilai Bau Kecap Ikan Layang Dengan Konsentrasi Nenas Yang Berbeda.

Walaupun secara statistik memberikan pengaruh yang tidak nyata, namun pada Gambar 4 menunjukkan terjadinya kecenderungan perbedaan nilai bau pada setiap perlakuan kecap ikan dengan konsentrasi yang berbeda. Nilai bau yang tertinggi terjadi pada perlakuan $\mathrm{K} 1$ $(200 \mathrm{ml})$ yaitu sebesar 2,425 dan yang terendah terjadi pada perlakuan (K3) dengan konsentrasi $300 \mathrm{ml}$ yaitu 2,225, sedangkan perlakuan $\mathrm{K} 2(250 \mathrm{ml})$ sebesar 2,338 . Hal ini dikarenakan pada perlakuan (K1) konsentrasi enzim yang ditambahkan lebih sedikit sehingga asam lemak bebas yang dihasilkan dari proses fermentasi lebih sedikit. Menurut (Winarno, 1997), pembentukkan aroma/bau berhubungan erat dengan senyawa-senyawa asam amino 
bebas yang terdapat pada akhir fermentasi. Asam amino bebas akan mengalami oksidasi dan terbentuklah asam lemak bebas.

\section{Nilai Warna}

Warna merupakan parameter pertama yang menentukan penerimaan konsumen untuk penilaian secara subyektif dengan penglihatan. Penentuan mutu bahan pangan pada umumnya sangat tergantung pada beberapa faktor seperti cita rasa, warna, tekstur, dan nilai gizi, juga sifat mikrobiologis dari bahan pangan tersebut. Sebelum faktor lain dipertimbangkan secara visual, faktor warna tampil terlebih dahulu dan kadang-kadang sangat menentukan dalam penilaian suatu bahan (Winarno, 1997).

Warna makanan memiliki peranan utama dalam penampilan makanan, meskipun makanan tersebut lezat. Bila penampilan tidak menarik, maka saat disajikan akan mengakibatkan selera orang yang ingin mengkonsumsinya akan hilang (Soeparno, 2005). Analisis sidik ragam warna kecap ikan layang memberikan pengaruh tidak nyata $(\mathrm{P}>0,05)$. Hal ini diduga karena jenis enzim yang digunakan pada setiap perlakuan adalah sama menyebabkan warna kecap ikan cenderung sama. Nilai rerata uji organoleptik terhadap warna tersaji di Gambar 5.

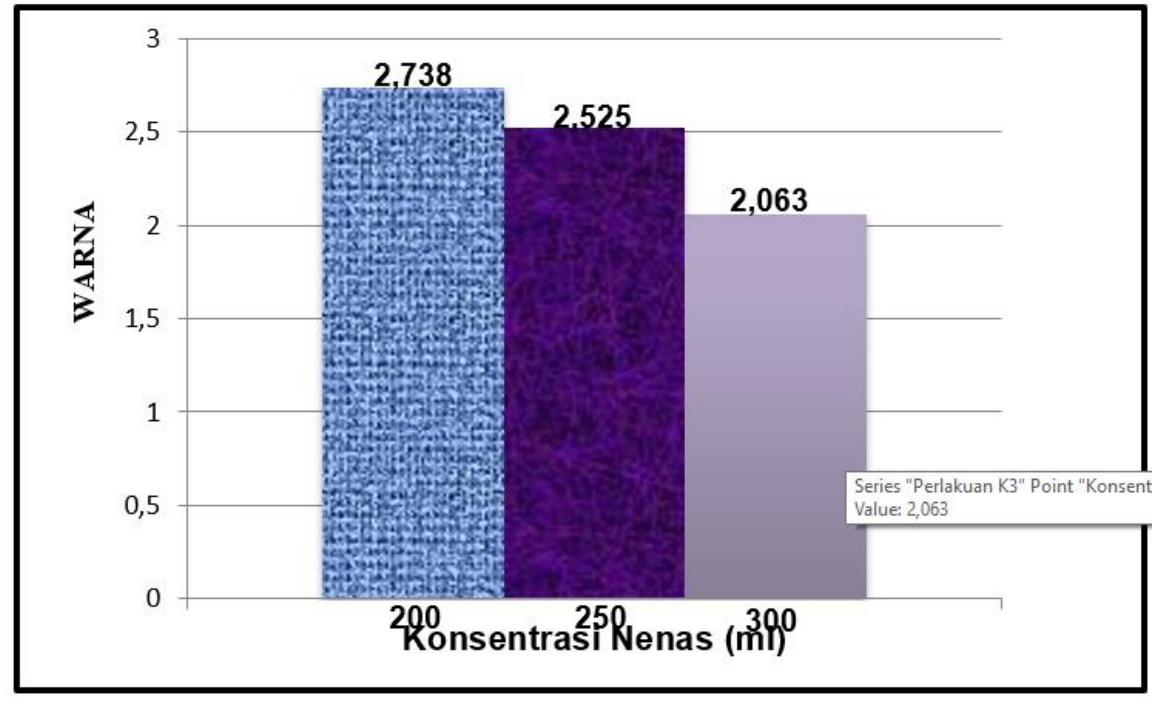

Gambar 5. Diagram Nilai Rerata Warna Kecap Ikan Dengan Konsentrasi Nenas Yang Berbeda.

Hasil penilaian panelis terhadap warna kecap ikan layang berkisar antara $2,063-2,738$ yang berarti tingkat kesukaan panelis mulai dari agak suka sampai suka. Penerimaan panelis terhadap warna dipengaruhi penampakan warna kecap ikan itu sendiri, dimana kecap ikan yang dihasilkan secara enzimatis berwarna coklat jernih. Hal ini berbeda dengan kecap yang diolah secara tradisional yang umumnya berwarna coklat pekat sehingga berpengaruh pada penilaian panelis terhadap warna kecap ikan yang relatif agak suka.

Tingkat kesukaan warna terendah terjadi pada perlakuan $\mathrm{K} 3(300 \mathrm{ml})$ sebesar 2,063 dan tertinggi 2,738 pada perlakuan K1 (200 ml), sedangkan K2 (250 ml) yaitu sebesar 2,525. Hal ini diduga pemberian konsentrasi enzim bromelin pada perlakuan (K3) lebih banyak sehingga warna kecap ikan yang dihasilkan kekuning-kuningan. 
KAUDERNI : Journal of Fisheries, Marine and Aquatic Science

https://jurnal.stplpalu.ac.id/index.php/kauderni/index

Volume 2, Nomor 2, (2020)

ISSN 2541-0571

https://doi.org/10.47384/kauderni.v2i2.48

\section{KESIMPULAN}

Berdasarkan hasil penelitian yang telah dilakukan maka dapat disimpulkan bahwa konsentrasi nenas (enzim bromelin) yang berbeda memberikan pengaruh sangat nyata terhadap mutu kimia (viskositas). Disamping itu, konsentrasi nenas $200 \mathrm{ml}$ memiliki nilai tertinggi pada viskositas $(3,698 \%)$. Sedangkan mutu organoleptik meliputi bau $(2,425)$, warna $(2,738)$.

\section{UCAPAN TERIMA KASIH}

Penulis menyampaikan terima kasih kepada Sekolah Tinggi Perikanan dan Kelautan palu yang telah meberikan kesempatan dalam melakukan penelitian.

\section{REFERENSI}

Adawyah, R. 2007. Pengolahan dan Pengawetan Ikan. Bumi Aksara. Jakarta.

British Standard. 1975. Sampling and testing of gelatin. dalam : Imeson (ed). 1992. Thickening and Gelling Agents. Academic Press, New York.

Hanafiah, K. A. 2001. Rancangan Percobaan Teori dan Aplikasi. Cetakan ke Tujuh. Penerbit PT. Utomoputer, Jakarta.
Hamidi, H. 2008. pengaruh enzim bromelin pada proses pembuatan kecap keong sawah terhadap kadar protein kecap keong sawah. Skripsi. Universitas Negeri Semarang. Semarang.

Muchtadi, D., M. Astawan dan N.S. Palupi. 2007. Pengetahuan Bahan Pangan Hewani. Universitas Terbuka press. Jakarta

Soekarto T.S. 1994. Penelitian Organoleptik Untuk Industri Pangan dan Hasil Pertanian. Bhratara, Jakarta.

Soeparno. 2005. Ilmu dan Teknologi Daging. Cetakan ke-4. Gadjah Mada University Press, Yogyakarta.

Steel, R.G.D and J.H. Torrie. 1991. Prinsip dan Prosedur Statistik Suatu Pendekatan Biometrik. Terjemahan, Judul Asli : Principle and Procedur Of Statistics, A Biometrical Approach. Penerjemah: B. Sumantri. PT Gramedia Pustaka Utama, Jakarta.

Suprapti, L.M. 2008. Produk-Produk Olahan Ikan. Kanisius. Yogyakarta.

Winarno, F.G. 1991. Kimia Pangan dan Gizi. Cetakan kelima. PT. Gramedia. Jakarta.

Winarno, F.G. 1997. Gizi, Teknologi dan Konsumen. Gramedia Pustaka Utama. Jakarta. 